\section{References}

1. Hart RS. Minimally invasive heart surgery. Circulation. 1996;94: 2669-70.

2. Massetti M, Babatasi G, Lotti A, Bhoyroo S, Le Page O, Khayat A. Less invasive cardiac operations through median sternotomy: 100 consecutive cases. Ann Thorac Surg. 1998;66:1050-4.

3. Novellino L, Longoni M, Spinelli L, Andretta M, Cozzi M, Faillace G, et al. "Extended" thymectomy, without sternotomy, performed by cervicotomy and thoracoscopic technique in the treatment of myasthenia gravis. Int Surg. 1994;79:378-81.

4. Mack MJ. Video-assisted thoracoscopy for myasthenia gravis: surgery for thymoma. Chest Surg Clin North Am. 2001;11:389-405.

5. Port JL, Ginsberg RJ. Surgery for thymoma. Chest Surg Clin North Am. 2001;11:421-37.

6. Shimokawa S, Watanabe S, Sakasegawa I, Tani A. Ruptured thymoma causing mediastinal hemorrhage resected via partial sternotomy. Ann Thorac Surg. 2001;71:370-2.

\title{
Aggressive multimodality treatment of invasive thymic carcinoma
}

\author{
Michael A. Greene, MD, FCCP, and Mark A. Malias, MD, FCCP, \\ Melbourne, Fla
}

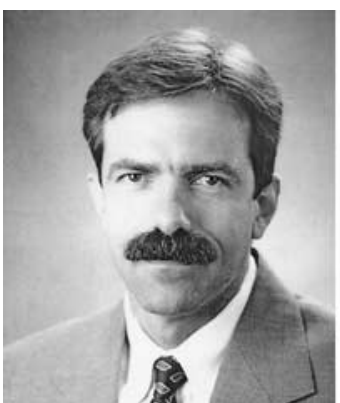

Greene

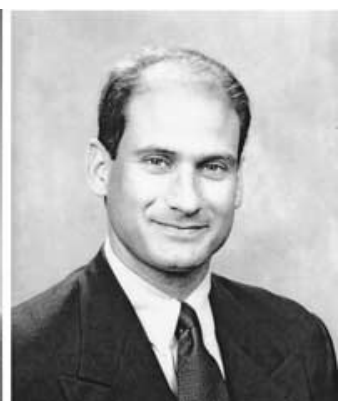

Malias
T hymic carcinomas are epithelial neoplasms of the thymus generally characterized by extensive local invasion and distant metastases. Overall prognosis is poor, with 5-year survivals of $31 \%$ to $50 \% .{ }^{1}$ Blumberg and associates $^{2}$ found innominate vessel invasion (vein or artery) to be the only statistically significant predictor of poor survival according to univariate analysis. We report a case of thymic carcinoma with extensive local invasion treated with en bloc surgical resection followed by chemotherapy and radiation.

\section{Clinical Summary}

A 48-year-old nonsmoking woman had an approximately 2-year history of intermittent chest discomfort attributed to costochondritis. After a day of vigorous physical exertion, she had acute shortness of breath and right-sided chest pain. She was treated with anti-inflammatory medications. However, a chest radiograph showed a prominent right hilum. She underwent chest computed tomographic and magnetic resonance imaging scans, which dem-

From Department of Surgery, University of Florida, Melbourne, Fla.

Received for publication May 29, 2002; accepted for publication July 15, 2002.

Address for reprints: Michael A. Greene, MD, FCCP, Health First Heart Institute, 1355 S. Hickory Street, Suite 202, Melbourne, FL 32901 (E-mail: mgreene@ health-first.org).

J Thorac Cardiovasc Surg 2003;125:434-6

Copyright $\odot 2003$ by The American Association for Thoracic Surgery

$0022-5223 / 2003 \$ 30.00+0$

doi: $10.1067 / \mathrm{mtc} .2003 .133$ onstrated a large $(8.5 \mathrm{~cm})$ anterior mediastinal mass (Figures 1 and 2). A biopsy specimen of the mass was obtained through a small anterior right parasternal incision, and moderately differentiated squamous cell thymic carcinoma was diagnosed (Figure 3).

The patient's en bloc surgical resection was extensive because of direct tumor invasion of the surrounding structures. Obtaining negative margins required resection of the right anterior chest wall with partial sternectomy, partial right lung upper lobectomy, and mediastinal soft tissue resection, including resection of the pleura, pericardium, and right phrenic nerve. Resection of tumor involvement of the innominate vein and superior vena cava was accomplished with systemic heparinization and the placement of a temporary shunt connecting the confluence of the right subclavian and jugular veins with the right atrium.

The superior vena cava was reconstructed with autologous pericardium. Transient sinus node dysfunction as a result of clamp occlusion of the superior vena caval-right atrial junction was treated during the operation with temporary atrial pacing.

The chest wall soft tissue defect was closed with a pectoralis rotational flap and local fasciocutaneous flap advancement. The patient was extubated after 3 days, with minimal paradoxic right chest wall excursion noted. An elevated right diaphragm as a result of phrenic nerve resection was observed, as expected, on the postoperative chest radiograph.

Oral anticoagulation therapy was started to prevent thrombosis of the extensive pericardial reconstruction of the innominate and superior caval veins. The patient was discharged after 11 days and later returned for outpatient placement of a femoral vein chemotherapy infusion port.

Subsequent treatment included chemotherapy consisting of 6 cycles of paclitaxel at $150 \mathrm{mg} / \mathrm{m}^{2}(255 \mathrm{mg})$ with 6 cycles of carboplatin (540 $\mathrm{mg}$ each dose), followed by radiation therapy (Table 1). Preoperative induction radiation of the tumor was 


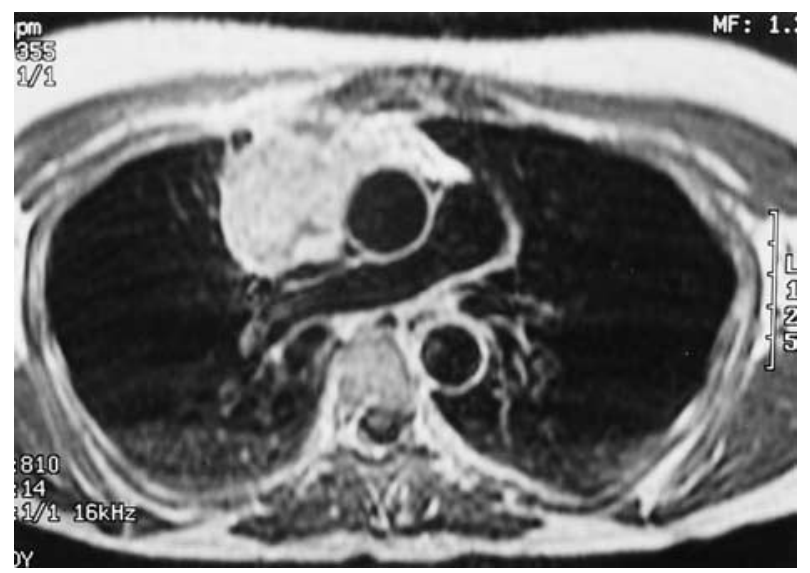

Figure 1. Preoperative radiographic tumor appearance.

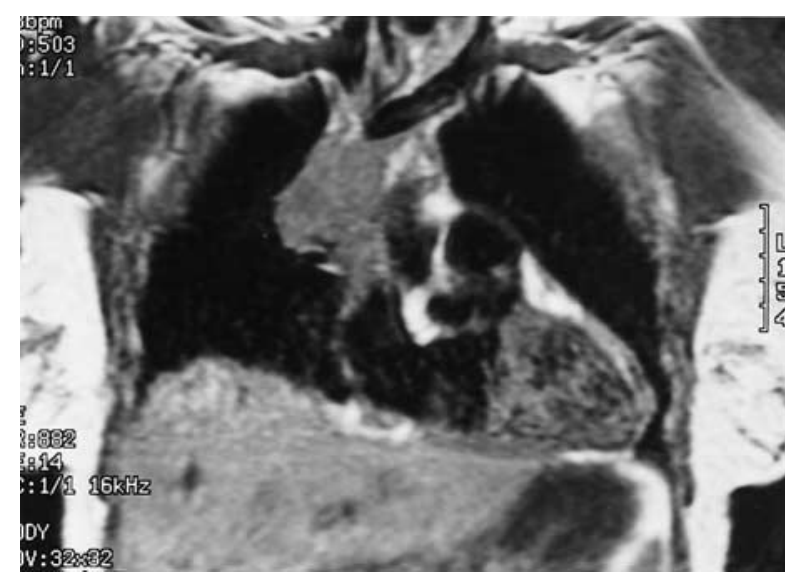

Figure 2. Preoperative radiographic tumor appearance.

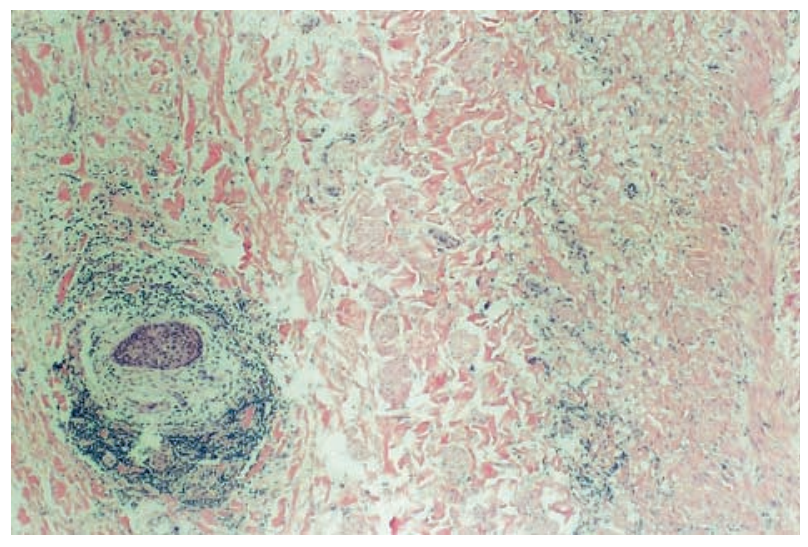

Figure 3. Photomicrograph of resected thymic carcinoma.

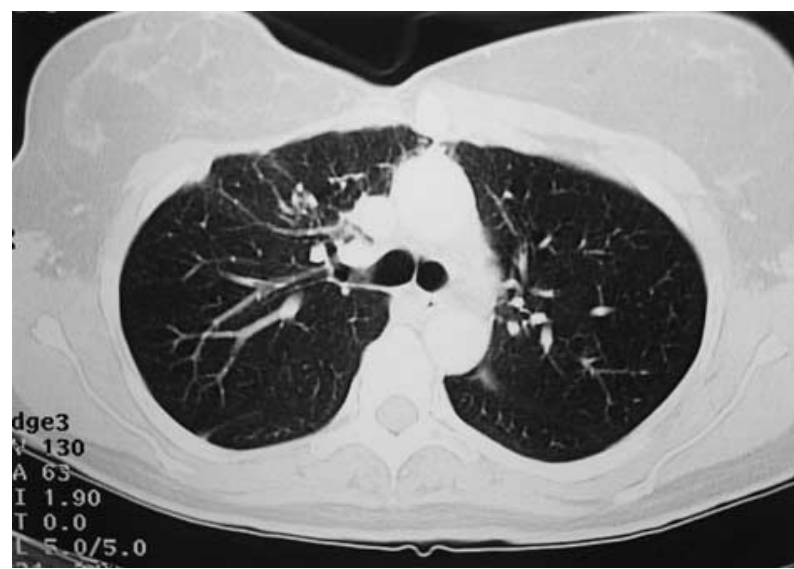

Figure 4. Postoperative scan of chest resection site without recurrence.

TABLE 1. Postoperative radiation treatment plan for thymic carcinoma

\begin{tabular}{|c|c|c|c|c|c|c|}
\hline Anatomic treatment site & Technique & Source & $\begin{array}{l}\text { Daily dose } \\
\text { (Gy) }\end{array}$ & $\begin{array}{c}\text { Total } \\
\text { treatments }\end{array}$ & $\begin{array}{l}\text { Elapsed time } \\
\text { (d) }\end{array}$ & $\begin{array}{l}\text { Site dose } \\
\text { (Gy) }\end{array}$ \\
\hline $\begin{array}{l}\text { Anterior mediastinum, } \\
\text { bilateral subclavian }\end{array}$ & $\begin{array}{l}\text { Anteroposterior, } \\
\text { posteroanterior }\end{array}$ & $6 / 15 x$ & $1.2^{*}$ & 36 & & 43.2 \\
\hline $\begin{array}{l}\text { Cone down anterior } \\
\text { mediastinum }\end{array}$ & $\begin{array}{l}\text { Anteroposterior mixed } \\
\text { beam }\end{array}$ & $6 x / 18 e$ & $1.2^{*}$ & 6 & & 7.2 \\
\hline $\begin{array}{l}\text { Cone down No. } 2 \\
\text { anterior mediastinum }\end{array}$ & $\begin{array}{l}\text { Right anterior oblique, } \\
\text { left anterior oblique }\end{array}$ & $6 x$ & $1.2^{*}$ & 8 & & 9.6 \\
\hline $\begin{array}{l}\text { Anterior mediastinum } \\
\text { total }\end{array}$ & & & & 50 & 36 & 60 \\
\hline
\end{tabular}

*Total dose, administered in 2 divided doses.

considered. However, concerns that the radiation would limit the surgeon's ability to determine tumor margins weighed on the decision to resect first and then apply postoperative radiation.

During follow-up, the patient had 2 episodes of swollen left upper extremity as a result of left subclavian venous obstruction; both episodes were treated with warfarin sodium with resolution of swelling. A computed tomographic scan performed 28 months after the operation showed no evidence of tumor recurrence (Figure 4). This disease-free interval is encouraging. However, the patient still requires close follow-up, because late recurrences are common with this tumor type. 


\section{Discussion}

Thymic carcinomas comprise only $0.06 \%$ of thymic neoplasms. The rarity of these tumors and differences in classification systems combine to make analysis of treatment outcomes problematic. Various treatment combinations with chemotherapy, radiation therapy, and surgery have been used to treat advanced lesions. ${ }^{3}$ Radical resections combined with chemotherapy and radiation, such as this case report, have been reported with favorable diseasefree survival. ${ }^{4}$ Other authors have also noted favorable trends among patients treated with postoperative radiation. ${ }^{5}$ Further clinical experience with aggressive multimodality therapy will be necessary to establish optimal protocols for the treatment of these tumors.

\section{References}

1. Chung DA. Thymic carcinoma-analysis of nineteen clinicopathological studies. Thorac Cardiovasc Surg. 2000;48:114-9.

2. Blumberg D, Burt ME, Bains MS, Downey RJ, Martini N, Rusch V, et al. Thymic carcinoma: current staging does not predict prognosis. J Thorac Cardiovasc Surg. 1998;115:303-8.

3. Nakamura Y, Kunitoh H, Kubota K, Sekine I, Shinkai T, Tamura T, et al. Platinum-based chemotherapy with or without thoracic radiation therapy in patients with unresectable thymic carcinoma. Jpn J Clin Oncol. 2000;30:385-8.

4. Takahashi K, Yoshida J, Nishimura M, Nagai K. Combined partial sternectomy for thymic carcinoma. Jpn J Thorac Cardiovasc Surg. 2000;48:586-9.

5. Hsu CP, Chen CY, Chen CL, Lin CT, Hsu NY, Wang JH, et al. Thymic carcinoma: ten years' experience in twenty patients. $J$ Thorac Cardiovasc Surg. 1994;107:615-20. 